ISSN 0258-7122

Bangladesh J. Agril. Res. 34(1) : 51-57, March 2009

\title{
INTERCROPPING OF HYBRID MAIZE WITH SHORT DURATION VEGETABLES AT HILL VALLEYS OF BANDARBAN
}

\author{
M. JAMAL UDDIN ${ }^{1}$, M.A. QUAYYUM² AND K.M. SALAHUDDIN ${ }^{3}$
}

\begin{abstract}
The experiment was conducted at farmer's field in Bandarban sadar areas daring rabi season 2004-05 and 2005-06 to find out the feasibility and profitability of growing short duration vegetables i.e., Potato (var. Heera,), lalsak (var. Red king,), spinach (var. local), and French bean (var. BARI Jharseem-2) with hybrid maize (var. Pacfic-11). The grain yield of sole maize was 9.65 t/ha whereas yield reduction was found in intercrop situation The maize equivalent yield showed that maize + spinach produced significantly higher yield (15.62 t/ha) followed by maize + lalsak (14.48 t/ha) and maize + potato (13.93 t/ha). Maize + spinach recorded the highest gross margin (Tk. 86,257/ha), but higher benefit cost ratio and marginal rate of return was accounted from maize + lalsak combination. The lowest gross margin was obtained from sole maize. It revealed that the combination of maize with lalsak or spinach were more compatible and profitable intercropping system in hill valleys of Bandarban areas.
\end{abstract}

Key Words: Intercropping, hybrid maize, short duration vegetables, profitable, hill valleys.

\section{Introduction}

Intercropping increases crop yield per unit area by intensifying the use of land. It does not only contribute to increase the productivity, but also increases the farmer's income (Villare, 1976). Inter cropping system is an important approach of cropping system for increasing crop yield. Plant competition is an inevitable phenomenon in intercropping system that reduces intercrop productivity. Greater productivity in intercropping system is commonly achieved by minimizing competition and minimizing complementary use of growth resources (Krishna and Raikhelker, 1997). Intercropping provides an opportunity to avoid crop competition and advantage of increased production and greater profit or margin (Evans, 1960; Gribines, 1963) and gives higher resource use efficiency (Hashem and Maniruzzaman, 1986).

It also increased land equivalent ratio (LER) to varying degrees (Mehta and De, 1980: Hashem et al., 1990). Islam et al. (2004) reported that maize and bush bean exhibited similar competitiveness in simultaneous sowing and resulted in the highest intercrop productivity in maize-bush bean intercropping system. They suggested that two rows of bush bean in between maize rows can be grown by

\footnotetext{
${ }^{1}$ Scientific Officer, On-Farm Research Division, BARI, Bandarban, ${ }^{2}$ Ex. Chief Scientific Officer, OFRD, BARI, Gazipu and ${ }^{3}$ Assistant Editor, BARI, Gazipur, Bangladesh.
} 
higher yield and monetary advantage. The maize + vegetables intercropping field experiment was conducted in different locations during rabi season 2005-06. Findings from different locations showed that the highest maize equivalent yield was obtained from Maize + Bush bean intercropping systems at Jamalpur, Maize + Spinach at Jessore, Mymensigh, and Rangpur, Maize + coriander (as vegetable) at Pabna. Maize + Red amaranth at Kushtia and Manikganj (OFRD, 2006). The association of bush bean with maize provides some $\mathrm{N}$ economy (Singh et al., 2000). Intercropping is widely practiced by the farmers of Bangladesh. Generally legumes in association with non-legumes not only helps in utilization of the nitrogen being fixed in the current growing season, but also helps in residual nutrients build up of the soil (Sharma et al., 1991).

Bandarban is an area that has an enormous potentiality for maize cultivation where 168 hectares land was covered by maize cultivation and its production was 180 mt. (BBS, 2004). Maize in Bandarban hilly areas not only cultivated in plain land, but also in existing shifting cultivation (Jhum) system. According to DAE, in 2006, 6900 ha of hill were covered by existing shifting cultivation where maize was $2^{\text {nd }}$ most important cereal crop. Now a days, the area of maize is increasing due to high local demand as well as high market price. Besides, the tribal people also grow maize in their existing their system. Traditionally, the mariners of Bandarban cultivate maize as a sole crop. On the other hand, different short duration vegetable crops were also cultivated as mono crop. Due to limited plain land in Bandarban, such intercropping system would be benefited for the farmers. So, some vegetable crops might be a good intercrop with maize. Farmers often demand for quick return from their crops, so they can get quick return by growing short duration vegetable crops with maize. However, suitable intercrops, local food habit and market demands are important factors for getting higher benefit. The present experiment was, therefore, undertaken to examine the frasibility of growing different short duration rabi vegetables with hybrid maize in bill valleys of Bandarban.

\section{Materials and Method}

The experiment was conducted on high land at hill valleys at Muslim para and Dolo para in Bandarban sadar areas during rabi season 2004-05 and 2005-06. The soil of the experimental field was sandy loam having $\mathrm{p}^{\mathrm{H}} 5.5$ and nitrogen $(\mathrm{N})$, zinc (Zn) and boron (B) was very low, but $\mathrm{P}, \mathrm{K}$ and $\mathrm{S}$ status was medium. The site represents the area of AEZ-29. The intercrops included in the treatments were potato (var. Heera), lalshak (var. Redking), spinach (var. local), and French bean (var. BARI Jharseern-2).The variety of maize was Pacific-11. The experiment was laid out in a randomized complete block design with five dispersed farmers replications. The unit plot size was $16 \mathrm{~m} \times 10 \mathrm{~m}$. Potato seeds were planted in between two rows of maize with seed to seed spacing $20 \mathrm{~cm}$, but 
French bean seeds were planted at double line with maintaining the spacing 30 $\mathrm{cm} \times 10 \mathrm{~cm}$. Other intercrops (spinach and lalsak) were seeded by broadcast method in whole plot. The seed rate of lalshak and spinach was $2 \mathrm{~kg} / \mathrm{ha}$ and 35 $\mathrm{kg} / \mathrm{ha}$, respectively. Sowing was made 26 November to 3 Dccember 2004 and 2005. Maize and all intercrop vegetable seeds were sown at the same time. Fertilizers were applied for maize @ 256-55-138-30-1 kg/ha N-P-K-S-B, and cowdung @ $5 \mathrm{t} / \mathrm{ha}$. One third $\mathrm{N}$ and all other fertilizers and cowdung were applied as basal and rest $1 / 3^{\text {rd }} \mathrm{N}$ were applied at 8-10-leaf stage and $1 / 3^{\text {rd }} \mathrm{N}$ at tasseling stage only in maize rows as soil placement. Additional fertilizers were not applied for intercrops. All intercrops were harvested within 60-70 days after sowing. The yield data of intercrops sere recorded by total harvested yield on unit plot basis and then converted into t/ha yield. The maize was harvested during 1-5 April 2005 and 10-16 April 2006. The yield contributing characters of maize were recorded from 10 randomly selected plants. The yield data were calculated by using the following yield conversion formula for maize:

Adjusted Yield $=$ CF X Plot yield, $\mathrm{CF}=\mathrm{M}-03(\mathrm{~N}) / \mathrm{M}-\mathrm{N}, \mathrm{CF}=$ Conversi- factor, $\mathrm{M}=$ Optimum number of plants, $\mathrm{N}=$ Number of missing plants, $0.3=$ Constant factor

Yield $=$ Adjusted plot yield $\times 10000 \mathrm{~m}^{2}$ Area $\times 100-$ MC\%/85 X 0.8, i.e. MC $18 \%$ Maize equivalent yield (MEY) was calculated by using the following formula: $\mathrm{MEY}=$ Maize grain yield (t/ha) $+\frac{\text { Yield of intercrop (vegetables) } \times \text { Price of intercrop (vegetables) }}{\text { Price of Maize }(\text { grain) }}$

Mean comparison among the treatments was made by LSD test and pooled analysis was done as because there was no significant variation in yield and yield parameters among the year. Finally, benefit-cost and marginal analysis were done based on prevailing local market price.

\section{Results and Discussion}

\section{Plant height and yield components of maize}

Plant height, grains/cob, cobs/plant, 1000-grain weight, and grain yields were signiricantly different among the treatments (Table 1). Maximum plant height was recorded from sole maize $281 \mathrm{~cm}$, but statistically identical to all treatments except maize + French bean. Plants $/ \mathrm{m}^{2}$ was not significantly affected by different treatments. Number of cobs $/ \mathrm{m}^{2}$ between sole maize and other intercrop combinations were almost similar except maize + spinach and it was not statistically significant. Sole maize showed highest grains/cob among the treatments whereas, other treatments were similar but lower than sole maize. Grain weight also showed higher in sole maize, but closely followed by maize + lalshak \& maize + French bean combinations. 


\section{Yield (Sole and intercrop)}

The highest grain yield was recorded from sole maize due to higher yield attributes and it was identical to maize + potato and maize + lalshak combination. But the grain yield of maize spinach and maize + French bean combination were statistically significantly different from other treatments. Among the intercrops, spinach and French bean reduced grain yield of maize considerably, but potato and lalshak showed reasonable yield. Straw yield was not significantly influenced by sole or intercrop combinations. Among the intercrops, potato showed higher yield followed by French bean. Lalshak and spinach also showed similar and reasonable yield as intercrop. Though considerable grain yield of maize was reduced by intercrops but it was compensated by intercrops yield (Table 2).

Table 1. Effect of intercrop combination on yield components of maize during 200405 and 2005-06 (pooled).

\begin{tabular}{l|l|l|l|l|l}
\hline $\begin{array}{c}\text { Treatment } \\
\text { combinations }\end{array}$ & $\begin{array}{c}\text { Plant height } \\
(\mathrm{cm})\end{array}$ & Plants/rn & $\begin{array}{c}\text { Number of } \\
\text { cobs/rn }\end{array}$ & $\begin{array}{c}\text { Number of } \\
\text { grains/cobs }\end{array}$ & $\begin{array}{c}\text { 1000-grain } \\
\text { wt (g) }\end{array}$ \\
\hline Maize+potato & 258 & 4.9 & 5.6 & 437 & 366 \\
Maize + lalshak & 274 & 5.0 & 6.3 & 451 & 394 \\
Maize + spinach & 265 & 4.8 & 5.3 & 457 & 354 \\
Maize + French & 254 & 4.9 & 5.7 & 447 & 386 \\
bean & & & & & \\
Maize sole & 281 & 5.0 & 6.4 & 532 & 399 \\
\hline LSD (0.05) & 25.91 & $\mathrm{~ns}$ & 11.94 & 48.60 & 41.64 \\
CV (\%) & 8.95 & 9.53 & 7.71 & 5.45 & 8.01 \\
\hline
\end{tabular}

NS: Not Significant

\section{Maize equivalent yield}

Intercrops yields were converted to maize yield on the basis of price. The highest maize equivalent yield was recorded from maize + spinach. All the intercrops with maize showed higher equivalent yield than sole maize. Maize + French bean did not perform well as concerned of equivalent yield (Table 2).

\section{Cost and return analysis}

Cost and return analysis of intercropping is shown in Table 3. The highest gross return Tk. 1,19.447/ha was received from maize + potato intercrop followed by Tk. 1,16.035 ha for maize + lalshak and Tk.1,13,229 for maize + spinach. The lowest gross return obtained was Tk. 79,390/ha from sole maize. The cost of cultivation was accounted as all operational cost paid by cash by the farmer's. 
The highest variable cost was incurred (Tk. 51354/ha) for maize and potato intercrop because of higher price for potato seeds. The lowest cost was calculated Tk.40.123/ha for sole maize. The highest gross margin was obtained (Tk. $86,257 /$ ha) for maize and spinach followed by Tk.72,800/ha for maize and lalsak and Tk. 68,122/ha for maize and potato intercropping. The lowest gross margin was obtained Tk. 39,267/ha from sole maize. Though highest gross margin was obtained from maize + spinach, but failed to show higher BCR than maize + lalsak because yield of lalsak and its gross return was higher. Besides, this combinations also showed slightly lower cost. All the intercropping system showed higher BCR than sole maize (Table 3). Dominance and marginal analysis also showed that maize + lalsak dominated over control (sole maize) and it's Marginal Rate of Return (MRR) was found 2065 percent which implies that additional Tk. 2065/ha would be earned if additional investment at Tk. 100/ha in respective treatment combination (Table 4).

Table 2. Yield of maize and vegetables intercrops 2004-05 and 2005-06 (Pooled).

\begin{tabular}{l|l|l|l|l}
\hline \multirow{2}{*}{$\begin{array}{c}\text { Treatment } \\
\text { combinations }\end{array}$} & \multicolumn{2}{c|}{ Yield of maize (t/ha) } & \multirow{2}{*}{$\begin{array}{c}\text { Intercrop } \\
\text { (vegetable) } \\
\text { yield (t/ha) }\end{array}$} & $\begin{array}{c}\text { Maize } \\
\text { equivalent yield } \\
\text { (t/ha) }\end{array}$ \\
\cline { 2 - 4 } & Grain yield & Straw yield & 6.22 & 13.93 \\
\hline Maize+potato & 8.11 & 17.26 & 4.67 & 14.48 \\
Maize + lalshak & 8.34 & 16.26 & 4.53 & 15.62 \\
Maize + spinach & 7.52 & 14.83 & 5.29 & 10.42 \\
Maize+Frenchbean & 7.35 & 15.36 & - & 9.65 \\
Maize sole & 9.39 & 13.08 & 1.41 & 1.05 \\
\hline LSD (0.05) & 1.19 & ns & 10.49 & 8.76 \\
CV (\%) & 14.67 & 7.29 & & \\
\hline
\end{tabular}

NS: Not Significant

Table 3. Cost and return analysis of maize-vegetables inter-cropping pattern in Bandarhan (average of 2004-05 and 2005-06).

\begin{tabular}{l|l|l|l|c}
\hline $\begin{array}{c}\text { Treatment } \\
\text { combination }\end{array}$ & $\begin{array}{c}\text { Gross return } \\
\text { (Tk./ha) }\end{array}$ & $\begin{array}{c}\text { Total variable cost of } \\
\text { cultivation (Tk./ha) }\end{array}$ & $\begin{array}{c}\text { Gross margin } \\
\text { (Tk./ha) }\end{array}$ & BCR \\
\hline Maize+potato & 119447 & 51354 & 68122 & 2.32 \\
Maize + lalshak & 116035 & 43235 & 72800 & 2.68 \\
Maize + spinach & 113229 & 44113 & 86257 & 2.67 \\
Maize+Frenchbean & 93090 & 42175 & 50915 & 2.22 \\
Maize sole & 79390 & 40123 & 39267 & 1.97 \\
\hline
\end{tabular}

Note: Market price of maize (dry grain) $=T \mathrm{k} .8 \mathrm{~kg}^{-1}$ and Straw $=T \mathrm{k} .0 .25 \mathrm{~kg}^{-1}$

Vegetable crops: Potato@Tk.8 kg-1, lalshak@Tk.10 kg-1, spinach@Tk.12 kg-1 and French bean@ $\mathrm{Tk} . \mathrm{kg}^{-1}$. 
Table 4. Marginal analysis of maize-vegetables inter-cropping pattern in Bandarhan (average of 2004-05 \& 2005-06).

\begin{tabular}{l|c|l|l|l|l}
\hline \multicolumn{1}{c|}{$\begin{array}{c}\text { Intercrop } \\
\text { combination }\end{array}$} & $\begin{array}{c}\text { Gross } \\
\text { margin } \\
\text { (Tk./ha) }\end{array}$ & $\begin{array}{c}\text { Total } \\
\text { variable cost } \\
\text { (Tk./ha) }\end{array}$ & $\begin{array}{c}\text { Marginal } \\
\text { gross margin } \\
\text { (Tk./ha) }\end{array}$ & $\begin{array}{c}\text { Marginal } \\
\text { variable cost } \\
\text { (Tk./ha) }\end{array}$ & $\begin{array}{c}\text { MRR* } \\
\text { (\%) }\end{array}$ \\
\hline Maize+potato & 86257 & 44113 & 13457 & 878 & 1533 \\
Maize + lalshak & 72800 & 43235 & 21885 & 1060 & 2065 \\
Maize+Frenchbean & 50915 & 42175 & 11648 & 2052 & 568 \\
Maize sole & 39267 & 40123 & - & - & - \\
\hline
\end{tabular}

*MRR= Marginal Rate of Return, $\quad$ Note: Maize = Potato combination was discarded due to irrational cost in respect of gross margin than other treatment by calculating dominance analysis.

\section{Farmer's feedback}

Farmers' opined that they generally cultivate maize as sole or sometimes with potato as boundary crop. But they are now convinced to cultivate lalsak or spinach as intercrop with maize in their fields for quick and higher economic return. Farmers did not face any pest or diseases attack, so farmer's have shown their keen interest to cultivate this hybrid maize with vegetable crops in large scale but seed of hybrid maize and potato are not available locally.

\section{Conclusion}

All the intercropping system showed higher benefit but lalsak and spinach with maize was found more profitable compared to sole maize.

\section{References}

B.B.S. 2004. Year Book of Agricultural Statistics of Bangladesh. Bangladesh Bureau of Statistics. Planning Division, Ministry of Planning, Dhaka, Bangladesh Pp: 61

DAE. 2006. Annual report of department of Agricultural Extension. Bandarhan hill district. Presented in Regional Review of Research and Extension Workshop held on 27-28 May 2006 in Hill Agricultural Research Station, Khagracharri.

Evans, A. C. 1960. Studies of intercropping maize or sorghum with groundnuts. East Africa Agricultural Journal 26(1): 1.10.

Grihines, B.C. 1963. Intercropping and alternate roe cropping cotton and maize. East Africa Agricultural Journal 28(3): 161-163.

Hashem, A., A. F.M. Maniruzzaman. 1986. Effect of intercropping maize with cowpea at varying plant population levels. Bangladesh Agron. J. 2(1): 15-25.

Hashem, A., A. F. M. Maniruzzaman and M.A. Akhtaruzzaman. 1990. Study on the productivity, profitability of potato intercropped with vegetables and relayed with onion. Bangladesh Agron. J. 3: 3 9-43. 
Islam, M. N., M.M. Haque and A. Hamid. 2004. Productivity and competitive interference in maize + bushbean intercropping system in different sowing dates. Bangladesh Journal of Agricultural Research 29(2): 200.

Krishna, A. and S. V. Raikhelkar. 1997. Crop complementary and competition in maize (Zea mays) when intercropped with different legumes. Indian J. Agric. Sci. 67: 291294.

Mehta. N. K. and R. Dey. 1980. Intercropping maize and sorghum with soybean. J. Agric. Sci. Camb. 95: 117-122

OFRD, 2006. Annual report of On-Farm Research Division, 2005-06, Bangladesh Agricultural Research Institute, Joydebpur, Gazipur. pp: 291-297

Singh. D. P.. N. S. Rana and R. P. Singh. 2000. Growth and yield of winter maize (Zea mays) as influenced by intercrops and nitrogen application. Indian J. Agron. 45: 515519.

Villarel. R. L. 1976. Observation on the multiple cropping in Taiwan. Philippines J. Crop Sci. 3: 2-8. 